\title{
The Public Prosecutor's Investigation Based on Article 39 of Law Number 18 of 2013 concerning Illegal Logging
}

\author{
Armen Wijaya $^{1}$, Zudan Arif Fakrulloh ${ }^{2}$ \\ Student Program Doctor of Law Borobudur University, Jl. Pemuda, RT.1/RW.3, \\ Rawamangun, Kec. Pulo Gadung, DKI Jakarta 13220, Indonesia ${ }^{1,2}$ \\ \{wijayaarmen@gmail.com ${ }^{1}$, cclsis@yahoo.com² $\left.{ }^{2}\right\}$
}

\begin{abstract}
Illegal logging is the activity of logging, transporting and selling timber, a form of real threat around borders that are illegal or do not have permission from local authorities. The purpose of this paper is to investigate the unlawful logging model carried out by the Public Prosecutor based on Article 39 of Law Number 18 of 2013 concerning illegal logging. This study uses a legal methodology with a literature approach which is part of qualitative research. We use existing data in the library and a functional system in these books. This study concludes that the investigation carried out by the Public Prosecutor is carried out based on the applicable criminal procedure law, but what the public Prosecutor needs to do is to look at the evidence findings that must strengthen the punishment for the forest destroyer.
\end{abstract}

Keywords: Public Prosecutors; Investigation; Illegal logging

\section{Introduction}

Forest resources are an essential component in supporting the sustainability of creatures of life that needs to be maintained and protected for current and future generations (Supriyanto, 2021b). Forests have fundamental functions that significantly affect life, including conservation functions, covered functions, and production functions. As a conservation function, forests have a role in the preservation of flora and fauna. Protected position, the forest has a role in preventing flooding, erosion, and so on. Forest in addition to functioning as the lungs of the earth, the forest also has the function of providing the needs of the community in general and especially for industrial development and export to support economic growth, protect the climate atmosphere and give good influence, provide natural beauty in general and especially in the form of nature reserves, wildlife reserves, hunting parks, and tourist parks, as well as a laboratory of science, education, and tourism, and is one element of national development strategy (Supriyanto, 2021a).

As the natural wealth of the nation and the state, the nation's rights and the state to the forest and the result need to be maintained and maintained so that the forest can fulfil its function as the nation's interests and the country itself. But humans as social beings should be able to guard the woods, but on the contrary what happens is that humans loot forest wood and damage forests without wanting to replant, and what happens flash flood disasters often occur, 
landslides and much more, the damage to forests in Indonesia is so vast and costs a lot to repair forests.

Forest destruction often occurs and negatively impacts the environment, one of which is the crime of illegal logging, which is unpredictable activities against forest conditions after existing logging. Forest protection is reflected in the lumberjack concession mechanism (granting rights, permits or land by the government) as a logical consequence of the licensing function as a means of control and supervision. In the process of management in the framework of forest utilization, a concept is needed to integrate efforts to use economic functions and efforts to protect environmental capabilities so that the environment remains harmonious and balanced in accordance with the principles of sustainable or sustainable forest management sustainable development.

The reality in the field today has shown that there is environmental damage, especially in forests that, in fact as habitats where living things live, excessive utilization that gives birth to negative impacts on the management of exploitation forests, which in the end leaves many problems, including forest damage is very worrying. One of them is illegal logging or often referred to as illegal logging. Illegal logging is an activity in forestry or a series of activities that include logging, transportation, management of illegal timber export activities, contrary to the rule of law, or actions that cause forest damage. Elements contained in the crime of unlawful logging include: the existence of an activity, logging, can damage the forest, there is a rule of law that prohibits and contrary to the rule of law.

This illegal logging practice is generally carried out by people who have official permission from the government in conducting logging and concession permit holders of Forest Authority Rights (HPH). However, if more detailed, the perpetrator of illegal logging is an organized group. The point is that the perpetrators involved in unlawful logging not only hold logging permits, including lumberjack workers, owners of capital, buyers, sellers and who have backing government officials and community leaders.

Based on this, the consequences incurred are certainly state losses. Thus, in addressing the rise of illegal logging crimes, the ranks of law enforcement officials (police investigators and PPns investigators whose scope of duty is responsible for forest management, prosecutors and judges) have invited Law No. 18 of 2013 on Prevention and Eradication of Forest Destruction (after this referred to as the Forest Destruction Prevention and Eradication Act)

\section{Methods}

This study uses a legal methodology with a literature approach which is part of qualitative research. We use existing data in the library and a functional system in these books. We use Law No. 18/2013 on Illegal Logging as a problem analysis tool.

\section{Discussion}

\subsection{The Role of the Prosecutor's Office in Investigating Illegal Logging}

Law enforcement, according to Soerjono Soekanto, conceptually from the core and the meaning of law enforcement is a combination of values described in the rules or views of good deals and the framework of the elaboration of the value of the final stage to create, maintain and maintain peace in the association of life (Ibnu Suka, Gunarto, 2018). Law 
enforcement against handling a criminal case is necessary to create a rule and function of legal norms in real life. Not only that, law enforcement can be said to be one of the efforts in dealing with crime rationally that meet the sense of justice and as a reaction given to the perpetrators of crimes.

In law enforcement against illegal logging in protected forest areas, it must be done well to do nothing similar in the future. However, this is a criminal act that, of course, has particular regulations. The two criteria that can indicate the special criminal law, namely: the first person or his specific subject, and the second his actions (bijzonderlijkfeiten). Its association with illegal logging crimes in the category of criminal law whose actions are particular, namely: forestry offences concerning the management of timber forest products. Illegal logging crimes, in general, can be associated with elements of common crimes in the Criminal Code, which are grouped into several forms of crime in general, namely: 1. Destruction, 2. Theft, 3. Smuggling, 4. Counterfeiting, 5. Embezzlement, and 6. Embezzlement.

In the investigation process, especially forestry crimes procedurally according to the Criminal Procedure Law provisions (KUHAP) must be initiated with the investigation (Joni, 2015: 75). Based on Article 7, Paragraph 2, the KUHAP relationship of Civil Servant Investigators (PPNS) certainly under the coordination and supervision of police investigators of the Republic of Indonesia (POLRI), namely: 1. The investigation, 2. The research, 3. Arrest, 4. Detention, 5. The prosecution, and 6. Examination in Court.

If it is connected between the theory of law enforcement put forward by SoerjonoSoekanto with law enforcement against the perpetrators of illegal logging crimes in Buleleng Regency, then judging by the factors that affect it are 1. Legal aspects, 2. Law Enforcement Factors, 3. Characteristics of Facilities or Supporting Facilities, 4. Community Factors, and 5. Cultural Factors.

\subsection{The Position of the Prosecutor in Criminal Settlement Cases}

The Prosecutor position in Indonesia is inseparable from the history of the Prosecutor's Office in this land (Rendra, 2019). The history of prosecutors in modern Indonesia began in the mid-nineteenth century when the Dutch colonial government invited IR (Inlandch Reglemen, or Reglement Bumi Putera) and RO (Reglement op de rechterlijke Organisatie, or Reglemen Organisasi Peradilan). IR formulated, among others, criminal procedural law. In contrast, RO composed a public prosecution body at the Bumi Putra Court and the European Court of Justice in the Dutch East Indies.

The Prosecutor's position in criminal justice in Indonesia has been shifted in line with the shift in duties and authority. With criminal justice, its responsibilities and powers are regulated in KUHAP, while its relation to institutions is handled separately in Law No. 16 of 2004 concerning Prosecutors.

To understand the position of the Prosecutor in criminal justice is inseparable from the provisions, namely article 2 paragraph (1) of Law No. 16 of 2004 concerning Prosecutors states that, "The Attorney General of the Republic of Indonesia is a Government Institution that exercises the power of the State in the field of Prosecution and other authorities based on the Law".

Article 1, number 1 of Law No. 16 of 2004 concerning Prosecutors states, "Prosecutors are functional officials authorized by law to act as public prosecutors and executors of court decisions that have obtained permanent legal force and other authority under the law".

I am referring to Law No. 16 of 2004, which replaces Law No. 5 of 1991 concerning the Attorney General's Office. As one of the law enforcement agencies, the Prosecutor's Office 
must play a more role in upholding the law's supremacy, protecting the public interest, enforcement of a human right, and eradicating corruption, Collusion and Nepotism (KKN).

This is because the Prosecutor's Office is in the diasporas and becomes a filter between the investigation process and the examination process in the Court and the executor of the determination and decision of the Court. Therefore, the Prosecutor's Office is the controller of the proceedings (Dominus Litis) because only the Prosecutor's Institution can determine whether a case can be submitted to the Court or not based on valid evidence of Criminal Procedural Law.

The position of prosecutors in almost every jurisdiction is a significant figure in the implementation of criminal justice; even in the international world, prosecutors do not conduct their investigations, prosecutors have a comprehensive policy (discretion) prosecution. Also, it determines whether a case proceeds to the trial to the Court or not.

\section{Conclusion}

Based on the things that have been stated above, can be concluded about the enforcement of the law against the perpetrators of illegal logging crimes in Indonesia are the following: Law enforcement against perpetrators of illicit logging crimes committed in protected forest areas has been appropriately enforced following Law No. 18 of 2013 on prevention and eradication of forest destruction carried out by law enforcement officials such as the Forest Service UPTD KPH, Forest Police, Police, Prosecutors, and Courts who are members of a unique team to eradicate illegal logging in Indonesia. Where the stages of law enforcement of the process of investigation, investigation, arrest, detention, prosecution, and examination in Court are running well following existing procedures and Efforts to combat the occurrence of illegal logging crimes are Penal and non-penal Countermeasures.

\section{References}

[1] Ardita, Mikho. 2020. "Tanggung Jawab Negara Terhadap Jaminan Kesehatan Dalam Perspektif Hak Asasi Manusia.” Jurnal HAM 11(2): 319-33.

[2] Ibnu Suka, Gunarto, U. M. (2018). Peran dan Tanggung Jawab Polri Sebagai Penegak Hukum dalam Melaksanakan Restorative Justive untuk Keadilan dan Kemanfaatan Masyarakat. Jurnal Hukum Khaira Ummah, 13(1), 111-118.

[3] Rendra, G. (2019). Kewenangan Penuntut Umum Dalam Penyidikan Perkara Pencegahan Pemberantasan Perusakan Hutan (P3H). Jurnal Yuridis, 6(2), 157. https://doi.org/10.35586/jyur.v6i2.1076

[4] Supriyanto, E. E. (2021). Konsep Pembangunan dan Pengembangan Ekowisata. In Pengantar Manajemen Potensi Desa: Aku Yakin Desaku Punya Sejuta Potensi (Vol. 1, Issue 1 , pp. 116-129). http://dx.doi.org/10.1016/j.cirp.2016.06.001\%0Ahttp://dx.doi.org/10.1016/j.powtec.20 16.12.055\%0Ahttps://doi.org/10.1016/j.ijfatigue.2019.02.006\%0Ahttps://doi.org/10.10 16/j.matlet.2019.04.024\%0Ahttps://doi.org/10.1016/j.matlet.2019.127252\%0Ahttp://dx .doi.o

[5] Supriyanto, E. E. (2021). Politik Kebijakan Ketahanan Pangan Indonesia Pasca Pandemi Covid-19. In Pertanian Dalam Ketahanan Pangan Selama dan Sesudah Covid-19 (Vol. 1, Issue 1, pp. 33-43). Penerbit Yayasan Guna Widya Paramesthi. 
